\title{
Strategi Berpikir Visual bagi Peserta Didik Gangguan Kecemasan Sosial untuk Mengembangkan Keterampilan Sosial
}

\author{
S. Sriyanto, Yudha Febrianta, Pratik Hari Yuwono \\ Program Studi Pendidikan Sekolah Dasar, Universitas Muhammadiyah Purwokerto \\ Email : sriyanto1907@gmail.com
}

\begin{abstract}
The purpose of this study is to develop the social skills of students who experience social anxiety disorder by using a visual thinking strategy learning model in elementary school. This study uses a quantitative approach, with the experimental method which is a series of methods that compare the experimental group with the control group. Data collection was carried out through pretest, posttest, and observation of two different classes. Data analysis techniques using SPSS with prerequisite tests for normality and homogeneity, for testing hypotheses using the $t$ test. Based on data analysis and discussion of the results of research that have been conducted, it can be concluded that there is an influence of Visual Thinking Strategies on the development of Social Skills for Students Social Anxiety Disorder, based on the SPSS calculation results obtained tcount $=2.659$, when compared with ttable $=$ 2.020 , the tcount value is greater from table or 2.659>2,020. From the test results it was concluded that visual thinking strategies can improve the social skills of students who experience social anxiety disorder.
\end{abstract}

Keyword: social skills, learners, social anxiety disorder, visual thinking strategies.

Abstrak. Tujuan penelitian ini adalah untuk mengembangkan keterampilan sosial peserta didik yang mengalami gangguan kecemasan sosial dengan menggunakan model pembelajaran strategi berpikir visual di sekolah dasar. Penelitian ini menggunakan pendekatan kuantitatif, dengan metode eksperimen yaitu serangkaian metode yang membandingkan kelompok eksperimen dengan kelompok kontrol. Pengumpulan data dilakukan melalui pretes, posttes, dan observasi terhadap di dua kelas yang berbeda. Teknik analisis data menggunakan SPSS dengan uji prasyarat Normalitas dan Homogenitas, untuk pengujian hipotesis menggunakan uji t. Berdasarkan analisis data dan pembahasan hasil penelitian yang telah dilakukan dapat diambil kesimpulan terdapat pengaruh Visual Thinking Strategies terhadap pengembangan Keterampilan Sosial bagi Peserta Didik Social Anxiety Disorder, berdasarkan hasil perhitungan SPSS diperoleh thitung $=2,659$, jika dibandingkan dengan ttabel $=2,020$, maka nilai thitung lebih besar dari ttabel atau 2,659 > 2,020. Dari hasil pengujian disimpulkan bahwa startegi berpikir visual (visual thinking startegies) dapat meningkatkan keterampilan social peserta didik yang mengalami gangguan kecemasan sosial.

Kata kunci: keterampilan sosial, peserta didik, social anxiety disorder, visual thinking strategies.

\section{PENDAHULUAN}

Keterampilan sosial adalah bagaimana anak dapat menjalin hubungan dengan anak yang lain living and working together, taking turns, respecting the right of others and being socially sensitive; learning self-control and self-direction; sharing ideas and experiences with others (Jarolimek, 1997:5). Upaya 
mengembangkan keterampilan sosial bagi anak-anak yang mengalami social anxiety disorder agar dapat membangun kepercayaan dirinya memerlukan tahapan yang konsisten. Melalui proses pembelajaran maka diharapkan anak-anak tersebut mampu membangun habituasi sehingga membantu dirinya sendiri memiliki kepercayaan dalam kehidupan sosialnya. Gambaran ini merujuk pada lima prinsip pembelajaran agar powerful atau tangguh sehingga guru dalam pembelajaran berpegang pada lima prinsip pembelajaran yaitu: bermakna (meaningful), terpadu (integrative), menantang (challenging), aktif (active), dan berbasis nilai (value based) (Sunal dan Haas, 2005:5).

Kesiapan mental anak untuk memasuki lingkungan ini menjadi prasyarat utama agar interaksi sosial anak tidak terganggu. Kesiapan mental anak ketika memasuki level pendidikan dasar lebih diutamakan dari perkembangan intelektual. Hal ini perlu menjadi perhatian bagi para orang tua dan guru di sekolah. Perkembangan psikologi anak sekolah dasar seperti diungkapkan oleh Peaget berada pada tahap concrete-operasional (7 11 tahun).

Anak usia Sekolah Dasar (7-11 tahun) adalahh usia memasuki usia remaja, sehingga mampu mengkoordinasikan pemikiran dengan peristiwa tertentu ke dalamsistem pemikirannya sendiri. Pada tahap ini, anak dianggap mampu mengkoordinasikan pandangan dari orang lain dengan pandangannya sendiri.

Lingkungan yang baru seringkali membuat anak mengalami hambatan untuk melakukan interaksi sosial. Kesan yang muncul terhadap lingkungan baru ini tergantung apa yang tertangkap dalam persepsi anak, dapat berupa kesan positif atau negatif, sehingga hal ini dapat berpengaruh terhadap perkembangan psikis anak (Lau, 2017). Anak yang mengalami gangguan kecemasan dapat dilihat dari ciri-cirinya yaitu hubungan yang kurang baik dengan guru dan temantemannya.

Salah satu upaya untuk mengembangkan keterampilan sosial bagi anak yang mengalami gangguan social anxiety disorder dengan model pembelajaran visual thinking strategies atau strategi berpikir visual adalah proses intelektual intuitif dan ide imajinasi visual, baik dalam pencitraan mental atau melalui gambar (Brasseur, 1991). Goldsmchmidt, 1994; Laseau, 1986) yaitu strategi pembelajaran mengandalkan proses berpikir bahasa gambar visual, bentuk, pola, tekstur, symbol. Namun visual thinking strategies memerlukan lebih banyak dari pada visualisasi atau representasi. John Steiner (1997) menyatakan bahwa visual thinking dapat mewakili sensasi pengetahuan dalam bentuk struktur ide, itu adalah aliran ide sebagai gambar, diagram, penjelasan model, lukisan yang diatur ide-ide besar dan penyelesaian sederhana.

Berdasarkan kondisi tersebut maka tujuan penelitian ini adalah untuk mengembangkan keterampilan sosial perserta didik yang mengalami gangguan kecemasan sosial.

\section{METODE}

Penelitian ini adalah penelitian quasi eksperimen, dengan melakukan treatment terhadap anak yang mengalami social anxiety disorder. Penelitian dilakukan di sekolah dasar Kecamatan Baturaden, Kabupaten Banyumas dengan menggunanakan sampel. Treatment yang dilakukan adalah menggunakan media bergambar dalam bentuk cerita (komik). Sampel penelitian diambil dari sekolah dasar untuk kelas rendah, dengan pertimbangan untuk mengetahui lebih dini peserta didik yang mengalami gangguan agar penanganannya dapat dilakukan sejak 
awal.

Penghitungan dan analisis data dalam suatu penelitian dimaksudkan untuk mengetahui makna dari data yang diperoleh dalam rangka memecahkan masalah penelitian. Adapun langkahlangkah dalam pengolahan data adalah sebagai berikut:

1. Menyeleksi data hasil tes, baik pretest maupun posttest, hasil observasi dan hasil wawancara yang terkumpul. Proses ini dilakukan karena mungkin saja terdapat perbedaan antara jumlah peserta tes dengan jumlah yang terkumpul, atau terdapat jawaban yang tidak diisi oleh siswa.

2. Memberikan skor pada tiap-tiap butir soal dalam data hasil tes sesuai dengan kriteria penilaian yang telah ditentukan.

3. Memasukkan atau melakukan input data dari skor tersebut pada program komputer Microsoft Excel.

4. Selanjutnya data tersebut diolah dan dianalisis dengan statistik dengan tujuan dapat memperoleh kesimpulan penelitian.

Analisis data dilaksanakan dengan menggunakan program Statistical Product and Service Solution (SPSS) dengan tahapan sebagai berikut:

1. Uji Normalitas

Uji normalitas data dilaksanakan dengan tujuan agar dapat memperoleh informasi apakah data berdistribusi normal atau tidak dengan menggunakan Korelasi Product Moment. Kondisi normalitas menjadi syarat pengujian hipotesis dengan ststistik parametrik. Selain itu, uji normalitas data juga akan menentukan langkah yang harus ditempuh selanjutnya, yaitu analisis statistik apa yang harus digunakan, apakah statistik parametrik atau non-parametrik. Jika hasil uji tidak normal dan tidak homogen, dilakukan uji non parametrik.
Langkah yang dilakukan adalah dengan menginput dan menganalisa menggunakan SPSS.

2. Uji Homogenitas

Uji homogenitas data dilaksanakan setelah uji normalitas data. Tujuan uji homogenitas data adalah untuk mengetahui apakah data tersebut berasal dari sampel atau populasi yang homogen atau tidak. Selain itu juga untuk menentukan jenis analisis statistik apa yang selanjutnya digunakan dalam uji hipotesis data. Karena syarat dari uji statistik parametrik, data penelitian harus berdistribusi normal dan homogen.

Melakukan Uji Homogenitas untuk menguji kesamaan (homogen) beberapa bagian sampel. Dalam penelitian ini perhitungan uji homogenitas menggunakan teknik pengujian statistic Lavene dibantu dengan program Statistical Product and Service Solution (SPSS) yang membandingkan nilai hasil pretest dan postest dengan ketentuan jika hitung lebih besar dari taraf signifikansi 0,05 maka nilai tes tersebut tidak memiliki perbedaan varian/ homogen.

3. Uji Hipotesis penelitian

Uji Hipotesis dalam penelitian ini dihitung dengan uji $-\mathrm{t}$ untuk mengetahui nilai rata-rata dari kedua kelompok tersebut memiliki perbedaan yang signifikan atau tidak. Jenis analisis statistik yang digunakan untuk melakukan uji hipotesis dalam rangka mencari kesimpulan ditentukan oleh hasil uji normalitas dan homogenitas data. Dalam uji hipotesis ini penulis membandingkan hasil pretes dan posttes kelompok eksperimen dengan kelompok kontrol. Pengujian dilakukan untuk mengetahui apakah ada pengaruh yang signifikan penggunaan visual thinking terhadap pengembangan 
keterampilan sosial pada siswa. Dengan menggunakan Gain skore sehingga hipotesis yang diajukan ada pengaruh Visual Thinking Strategies terhadap pengembangan Keterampilan Sosial (Social Skills) bagi Peserta Didik Social Anxiety Disorder.

\section{HASIL DAN PEMBAHASAN}

\subsection{HASIL}

Penelitian ini dilaksanakan pada peserta didik sekolah dasar di Kecamatan Baturaden, Kabupaten Banyumas. Sampel pada penelitian ini ialah peserta didik yang mengalami gangguan social anxiety disoreder yang duduk di level sekolah dasar. Jumlah siswa kelompok kontrol (kelas A) adalah 23 siswa, sedangkan jumlah kelompok eksperimen (kelas B) adalah 20 siswa. Siswa pada kedua kelompok tersebut diminta untuk mengerjakan soal pre test sebelum pelaksanaan penelitian berlangsung. Tujuannya ialah untuk mengetahui kemampuan awal siswa.

Berdasarkan hasil pre test dapat ditentukan bahwa kelas B sebagai kelompok eksperimen, sedangkan kelas A sebagai kelompok kontrol. Pelaksanaan penelitian pada masing-masing kelompok dilakukan selama dua kali pertemuan. Pembelajaran pada setiap pertemuan, baik di kelompok eksperimen maupun di kelompok kontrol ialah 2 × 35 menit.

Pelaksanaan pembelajaran pada kelompok eksperimen dan kelompok kontrol dengan materi pembelajaran serta instrumen penelitian yang sama, perbedaannya ialah perlakuan yang diberikan pada saat pembelajaran. Pendekatan pembelajaran yang digunakan yaitu pendekatan visual thinking strategies. Instrumen yang digunakan ialah pre test dan post test. Pembelajaran pada kelompok eksperimen dengan diberi perlakuan, yaitu menggunakan pendekatan visual thinking strategies, sedangkan pembelajaran di kelas kontrol menggunakan pembelajaran langsung.

1. Hasil Pre Test

a. Kelompok Eksperimen (Kelas B)

Berdasarkan perhitungan yang telah dilakukan, dapat diketahui

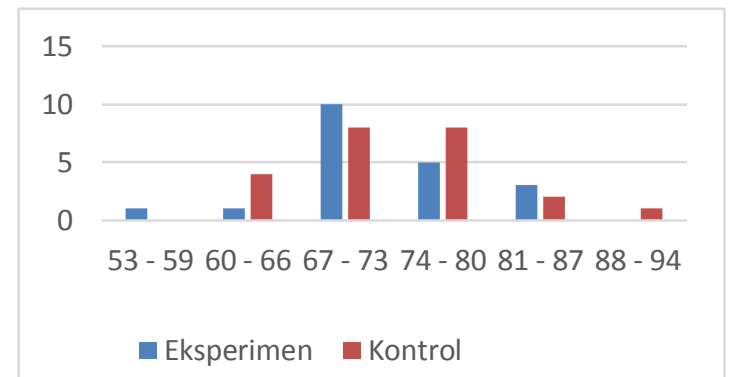

bahwa skor dilakukan, dapat diketahui bahwa skor tertinggi ialah 87 dan skor terendah ialah 53. Rata-rata nilai pre test untuk kelompok eksperimen yaitu 74,60. Hasil pre test kelompok eksperimen dapat dilihat pada tabel berikut ini:

Tabel 1. Distribusi Frekuensi Pre Test Kelompok Eksperimen

\begin{tabular}{ccc}
\hline No & Kelas & Frekuensi \\
& Interval & \\
\hline $\mathbf{1}$ & $53-59$ & 1 \\
\hline $\mathbf{2}$ & $60-66$ & 1 \\
\hline $\mathbf{3}$ & $67-73$ & 10 \\
\hline $\mathbf{4}$ & $74-80$ & 5 \\
\hline $\mathbf{5}$ & $81-87$ & 3 \\
\hline & Jumlah & 20 \\
\end{tabular}

b. Kelompok kontrol (Kelas A)

Berdasarkan perhitungan yang telah dilakukan, dapat diketahui bahwa skor tertinggi ialah 93 dan skor terendah ialah 60 . Rata-rata nilai pre test kelompok kontrol yaitu 74,74. Hasil pre test kelompok kontrol dapat dilihat pada tabel berikut ini:

Tabel 2. Distribusi Frekuensi Pre Test Kelompok Kontrol 


\begin{tabular}{ccc}
\hline No & Kelas & Frekuensi \\
& Interval & \\
\hline $\mathbf{1}$ & $53-59$ & 1 \\
\hline $\mathbf{2}$ & $60-66$ & 1 \\
\hline $\mathbf{3}$ & $67-73$ & 10 \\
\hline $\mathbf{4}$ & $74-80$ & 5 \\
\hline $\mathbf{5}$ & $81-87$ & 3 \\
\hline & Jumlah
\end{tabular}

Berdasarkan distribusi frekuensi pre test kelompok eksperimen dan kelompok kontrol, maka dapat digambarkan dalam histogram sebagai berikut:

Gambar 1. Histogram Pre Test Kelompok Eksperimen dan Kelompok Kontrol

Langkah selanjutnya setelah mendapat data awal adalah menguji normalitas dan homogenitas kedua data yang berasal dari kelas eksperimen dan kelas kontrol. Uji normalitas digunakan untuk mengetahui data yang digunakan berdistribusi normal atau tidak, sedangkan uji homogenitas digunakan untuk mengetahui siswa di kelas A dan siswa di kelas B memiliki kemampuan yang sama atau tidak. Perhitungan uji normalitas dan uji homogenitas data kelompok eksperimen dan kelompok kontrol sebagai berikut:

c. Uji Normalitas Data Pre Test

Uji normalitas pre test dilakukan dengan membandingkan hitung dan tabel. Kriteria pengujian uji normalitas data yaitu: jika hitung $\geq$ tabel maka data berdistribusi tidak normal dan jika hitung $\leq$ tabel maka data berdistribusi normal. Berdasarkan hasil perhitungan, bahwa data pre test kelompok eksperimen dan kelompok kontrol berdistribusi normal. Hasil perhitungan uji normalitas sebagai berikut:

Tabel 3. Uji Normalitas Pre test

\begin{tabular}{cccccc}
\hline Kelompok & $\mathbf{A}$ & $\mathbf{X}^{2}$ hitung & $\mathbf{X}^{2}$ tabel & Dk & Keterangan \\
\hline Eksperimen & 0,05 & 3,50 & 9,488 & $5-1$ & Normal \\
\hline Kontrol & 0,05 & 0,99 & 9,488 & $5-1$ & Normal \\
\hline
\end{tabular}

Hasil perhitungan uji normalitas pre test menggunakan SPSS dapat diketahui bahwa sig. kelompok eksperimen $=0,056$ dan sig. kelompok kontrol $=0,059$, kemudian dibandingkan dengan $\alpha=0,05$. Apabila sig. lebih besar dari $\alpha$, maka data berdistribusi normal. Berdasarkan perbandingan tersebut, data pre test kelompok eksperimen dan kelompok kontrol berdistribusi normal.

d. Uji Homogenitas Data Pre Test
Uji homogenitas dilakukan dengan membandingkan nilai Fhitung dengan Ftabel. Kriteria uji homogenitas ialah: jika Fhitung s Ftabel maka varians homogen dan jika Fhitung $\geq$ Ftabel maka varians tidak homogen. Berdasarkan hasil perhitungan, dapat diketahui bahwa data pre test kelompok eksperimen dan kelompok kontrol adalah homogen. Tabel 4 menunjukkan hasil perhitungan uji homogenitas.

Tabel 4. Uji Homogenitas Pre Test 


\begin{tabular}{ccccc}
\hline Kelompok & Fhitung & Ftabel & Varians & Ket \\
\hline Eksperimen & & & 74,88 & Homogen \\
\cline { 1 - 3 } & 1,04 & 2,08 & & \\
\cline { 1 - 1 } & & & & 72,11
\end{tabular}

Hasil perhitungan uji homogenitas pre test menggunakan SPSS dapat diketahui bahwa sig. = 0,566. Perhitungan tersebut kemudian dibandingkan dengan $\alpha=0,05$. Apabila sig. lebih besar dari $\alpha$, maka data homogen. Berdasarkan perbandingan tersebut, dapat disimpulkan bahwa kelompok eksperimen dan kelompok kontrol adalah homogen.

2. Hasil Post Test

Penilaian post tes diperoleh dari kelas eksperimen dan kelas kontrol. Angket dan post test diberikan kepada siswa di akhir pembelajaran pada pertemuan kedua.

Data hasil prestasi belajar siswa diketahui dari hasil post test yang telah diisi oleh siswa. Peneliti memperoleh data dari siswa kelompok eksperimen dan kelompok kontrol. Berikut ini hasil prestasi belajar siswa:

a. Kelompok Eksperimen (Kelas B)

Berdasarkan perhitungan yang telah dilakukan, dapat diketahui bahwa skor tertinggi adalah 100 dan skor terendah adalah 67. Rata-rata skor post test kelas eksperimen ialah 82,30. Hasil post test kelompok eksperimen dapat dilihat pada tabel berikut:

Tabel 5. Distribusi Frekuensi Post Test Kelompok Eksperimen

\begin{tabular}{ccc}
\hline No & $\begin{array}{c}\text { Kelas } \\
\text { Interval }\end{array}$ & Frekuensi \\
\hline 1 & $66-72$ & 1 \\
\hline 2 & $73-79$ & 5 \\
\hline
\end{tabular}

\begin{tabular}{rrr}
\hline 3 & $80-86$ & 5 \\
\hline 4 & $87-93$ & 8 \\
\hline 5 & $94-100$ & 1 \\
\hline & Jumlah & 20 \\
\hline
\end{tabular}

b. Kelompok Kontrol (Kelas A)

Berdasarkan perhitungan yang telah dilakukan, dapat diketahui bahwa skor tertinggi adalah 93 dan skor terendah adalah 60. Rata-rata post test kelompok kontrol ialah 75,35. Hasil post test kelompok kontrol dapat dilihat pada tabel berikut:

Tabel 6. Distribusi Frekuensi Post Test

\begin{tabular}{ccc}
\multicolumn{3}{c}{ Kelompok Kontrol } \\
\hline No & Kelas & Frekuensi \\
& Interval & \\
\hline 1 & $60-66$ & 2 \\
\hline 2 & $67-73$ & 10 \\
\hline 3 & $74-80$ & 8 \\
\hline 4 & $81-87$ & 2 \\
\hline 5 & $88-94$ & 1 \\
\hline & Jumlah & 23 \\
\hline
\end{tabular}

Berdasarkan distribusi frekuensi hasil post test kelompok eksperimen dan kelompok kontrol, maka dapat digambarkan dalam histogram sebagai berikut: 


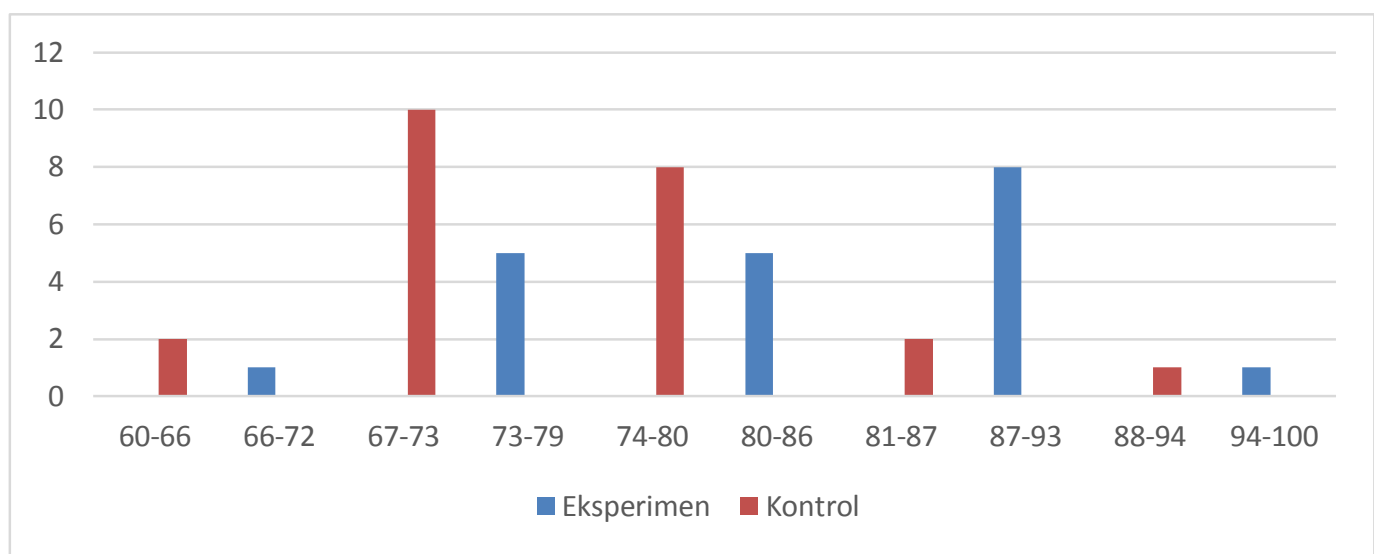

Gambar 2. Histogram Post Test Kelompok Ekperimen dan Kelompok Kontrol

Langkah selanjutnya sebelum dilakukan uji hipotesis maka terlebih dahulu dilakukan uji normalitas dan uji homogenitas data hasil post test kelompok eksperimen dan kelompok kontrol. Hasil uji normalitas dan uji homogenitas data post test kelompok eksperimen dan kelompok kontrol sebagai berikut:

c. Uji Normalitas Data Post Test

Uji normalitas post test dilakukan dengan membandingkan hitung dan tabel. Kriteria pengujian uji normalitas data yaitu: jika hitung $\geq$ tabel maka data berdistribusi tidak normal dan jika hitung $\leq$ tabel maka data berdistribusi normal. Berdasarkan hasil perhitungan, bahwa data post test kelompok eksperimen dan kelompok kontrol berdistribusi normal. Hasil perhitungan uji normalitas post test sebagai berikut:

Tabel 7. Uji Normalitas Data Post test

\begin{tabular}{cccccc}
\hline Kelompok & A & $\mathbf{X}^{2}$ hitung & $\mathbf{X}^{2}$ tabel & Dk & Keterangan \\
\hline Eksperimen & 0,05 & 2,49 & 9,488 & $5-1$ & Normal \\
\hline Kontrol & 0,05 & 1,92 & 9,488 & $5-1$ & Normal
\end{tabular}

Hasil perhitungan uji normalitas post test menggunakan SPSS dapat diketahui bahwa sig. kelompok eksperimen $=0,253$ dan sig. kelompok kontrol $=0,189$, kemudian dibandingkan dengan $\alpha=0,05$. Apabila sig. lebih besar dari $\alpha$, maka data berdistribusi normal. Berdasarkan perbandingan tersebut, data post test kelompok eksperimen dan kelompok kontrol berdistribusi normal. Hasil perhitungan uji normalitas post test dapat dilihat pada lampiran 3 halaman 163. d. Uji Homogenitas Data Post Test

Uji homogenitas dilakukan dengan membandingkan nilai Fhitung dengan Ftabel. Kriteria uji homogenitas ialah: jika Fhitung $\leq$ Ftabel maka varians homogen dan jika Fhitung $\geq$ Ftabel maka varians tidak homogen. Berdasarkan hasil perhitungan, dapat diketahui bahwa data post test kelompok eksperimen dan kelompok kontrol adalah homogen. Hasil perhitungan uji homogenitas sebagai berikut tabel 8 : 
Tabel 8. Uji Homogenitas Pre Test

\begin{tabular}{|c|c|c|c|c|}
\hline Kelompok & Fhitung & $F_{\text {tabel }}$ & Varians & Ket \\
\hline Eksperimen & & & 76,85 & \\
\hline & 1,19 & 2,08 & & Homogen \\
\hline Kontrol & & & 64,62 & \\
\hline
\end{tabular}

Hasil perhitungan uji homogenitas post test menggunakan SPSS dapat diketahui bahwa sig. = 0,706 . Perhitungan tersebut kemudian dibandingkan dengan $\alpha=0,05$. Apabila sig. lebih besar dari $\alpha$, maka data homogen. Berdasarkan perbandingan tersebut, dapat disimpulkan bahwa kelompok eksperimen dan kelompok kontrol adalah homogen. Hasil perhitungan uji homogenitas post test dapat dilihat pada lampiran 3 halaman 169.

\section{Uji Hipotesis}

Berdasarkan hasil uji normalitas data angket tanggungjawab dan post test, maka uji hipotesis menggunakan uji t karena data kelompok eksperimen dan kelompok kontrol berdistribusi normal. Hasil perhitungan uji hipotesis sebagai berikut:

Pengaruh Visual Thinking Strategies terhadap pengembangan Keterampilan Sosial bagi Peserta Didik Social Anxiety Disorder.

Berdasarkan hasil perhitungan uji hipotesis post test menggunakan SPSS memberikan kesimpulan yang sama dengan perhitungan secara manual, yaitu Ho ditolak dan Ha diterima. Berdasarkan hasil perhitungan SPSS diperoleh thitung = 2,659, jika dibandingkan dengan ttabel = 2,020, maka nilai thitung lebih besar dari ttabel atau 2,659>2,020., maka Ho ditolak dan Ha diterima. Artinya bahwa terdapat pengaruh Visual Thinking Strategies terhadap pengembangan Keterampilan Sosial (Social Skills) bagi Peserta Didik Social Anxiety Disorder.

\subsection{PEMBAHASAN}

Penelitian ini dilaksanakan pada peserta didik sekolah dasar di Kecamatan Baturaden, Kabupaten Banyumas. Sampel pada penelitian ini ialah peserta didik yang mengalami gangguan social anxiety disoreder yang duduk di level sekolah dasar. Jumlah siswa kelompok kontrol (kelas A) adalah 23 siswa, sedangkan jumlah kelompok eksperimen (kelas B) adalah 20 siswa. Siswa pada kedua kelompok tersebut diminta untuk mengerjakan soal pre test sebelum pelaksanaan penelitian berlangsung. Tujuannya ialah untuk mengetahui kemampuan awal siswa.

Berdasarkan hasil pre test dapat ditentukan bahwa kelas B sebagai kelompok eksperimen, sedangkan kelas A sebagai kelompok kontrol. Pelaksanaan penelitian pada masing-masing kelompok dilakukan selama dua kali pertemuan. Pembelajaran pada setiap pertemuan, baik di kelompok eksperimen maupun di kelompok kontrol ialah $2 \times 35$ menit.

Pelaksanaan pembelajaran pada kelompok eksperimen dan kelompok kontrol dengan materi pembelajaran serta instrumen penelitian yang sama, perbedaannya ialah perlakuan yang diberikan pada saat pembelajaran. Pendekatan pembelajaran yang digunakan yaitu pendekatan visual thinking strategies. Instrumen yang digunakan ialah pre test dan post test. Pembelajaran pada kelompok eksperimen dengan diberi perlakuan, yaitu menggunakan pendekatan visual thinking strategies, 
sedangkan pembelajaran di kelas kontrol menggunakan pembelajaran langsung.

\section{Pengaruh Visual Thinking} Strategies terhadap pengembangan Keterampilan Sosial bagi Peserta Didik Social Anxiety Disorder.

Berdasarkan hasil perhitungan uji hipotesis post test menggunakan SPSS memberikan kesimpulan yang sama dengan perhitungan secara manual, yaitu Ho ditolak dan Ha diterima. Berdasarkan hasil perhitungan SPSS diperoleh thitung = 2,659, jika dibandingkan dengan ttabel = 2,020, maka nilai thitung lebih besar dari ttabel atau 2,659>2,020., maka Ho ditolak dan Ha diterima. Artinya bahwa terdapat pengaruh Visual Thinking Strategies terhadap pengembangan Keterampilan Sosial (Social Skills) bagi Peserta Didik Social Anxiety Disorder.

Berdasarkan perhitungan yang telah dilakukan dengan menggunakan SPSS untuk menjawab hipotesis "pengaruh Visual Thinking Strategies terhadap pengembangan Keterampilan Sosial (Social Skills) bagi Peserta Didik Social Anxiety Disorder"

Hasil perhitungan uji hipotesis post test menggunakan SPSS memberikan kesimpulan yang sama dengan perhitungan secara manual, yaitu Ho ditolak dan Ha diterima. Berdasarkan hasil perhitungan SPSS diperoleh thitung = 2,659, jika dibandingkan dengan ttabel = 2,020, maka nilai thitung lebih besar dari ttabel atau 2,659 > 2,020. Artinya bahwa terdapat pengaruh Visual Thinking Strategies terhadap pengembangan Keterampilan Sosial (Social Skills) bagi Peserta Didik Social Anxiety Disorder.

Proses pembelajaran pada kelompok eksperimen dan kelompok kontrol menggunakan materi pembelajaran yang sama dan menggunakan instrumen sama.
Perbedaanya yaitu pada proses pembelajaran, kelompok eksperimen mendapat perlakuan yaitu menggunakan model pembelajaran pendekatan visual thinking strategies, sedangkan pada kelompok kontrol tidak mendapat perlakuan melainkan menggunakan pembelajaran langsung yang biasa digunakan oleh guru dalam pembelajaran.

Nilai tertinggi hasil post test pada kelompok eksperimen ialah 100, nilai terendah 67 , dan rata-rata yang diperoleh 82,30, sedangkan nilai tertinggi pada kelompok kontrol ialah 93, nilai terendah 60, dan rata-rata yang diperoleh 75,35. Hasil belajar siswa kelompok eksperimen menunjukkan hasil yang lebih tinggi. Adanya perlakuan yang berbeda dapat memberikan pengaruh yang berbeda pada prestasi belajar siswa kelompok eksperimen dan kelompok kontrol.

Keterampilan (skills) menurut Jarolimek (1977) diartikan sebagai suatu kemampuan dari hasil belajar melakukan sesuatu secara cakap dan nampak dalam tindakan yang dilakukan secara berulang. Artinya disini keterampilan (skill) merupakan tindakan yang harus difahami oleh peserta didik.

Pandangan Jarolimek mengenai keterampilan sosial terdiri tiga kecakapan utama yaitu: living and working together, taking turns, respecting the right of others and being socially sensitive, learning self-control and self-direction,sharing ideas and experiences with others. Begitu pula dengan pengertian lain yang dikemukakan oleh Sjamsuddin dan Maryani (2008:6), adalah;

Suatu kemampuan secara cakap yang tampak dalam tindakan ;mampu mencari, memilah dan mengolah informasi, mampu mempelajari hal-hal baru untuk memecahkan masalah sehari-hari, memiliki keterampilan berkomunikasi baik lisan maupun tulisan, memahami 
menghargai dan mampu bekerjasama dengan orang lain yang majemuk, mampu mentransformasikan kemampuan akademik dan beradaptasi dengan perkembangan masyarakat global.

NCSS pun menjabarkan keterampilan sosial ini kedalam tiga aspek, namun satuan tugas dari NCSS ini, menyebut keterampilan sosial ini dengan istilah keterampilan dengan interpersonal dan partisipasi sosial. Adapun aspekaspek tersebut adalah keterampilan personal, keterampilan interaksi kelompok, keterampilan partisipasi sosial dan politis.

Tidak banyak perbedaan dari ketiga peryataan tersebut, NCSS menerangkan bahwa dengan keterampilan sosial akan menumbuhkan keberanian mengeluarkan berpendapat, dapat menghargai pendapat orang lain yang berbeda dengan dirinya. Jika keterampilan ini sudah terjalin dalam kelompok maka biasanya kelompok tersebut akan memberikan kontribusinya ke dalam masyarakat dalam bentuk partisipasi sosial dan politis. Sehingga tumbuh rasa tanggung jawab kepada masyarakat lebih jauhnya ke dalam negara. Hal inilah yang menandakan bahwa pembelajaran yang mengajarkan keterampilan sosial dapat menunjang pembelajaran terutama membentuk warga negara yang baik dan bertanggung jawab terhadap bangsa dan negaranya.

Berdasarkan pengertian tersebut, maka indikator keberhasilan atau kemampuan peserta didik dalam keterampilan sosial yaitu peserta didik mampu untuk:

a. Hidup dan bekerja sama dengan yang lain, yang dimaksud dengan hidup bekerja sama dengan yang lain yaitu:

1) Memberikan kesempatan kepada orang lain di dalam kelompok untuk sama-sama mendapatkan hak dan kewajiban yang sama.
2) Membiasakan anggota kelompok untuk saling menghormati dan berpandangan positif kepada anggota yang lain.

3) Peka terhadap sesama sehingga turut merasakan dan mau menolong kesulitan atau penderitaan orang lain.

b. Belajar mengontrol diri dan pimpinan. Di dalam sebuah kelompok, untuk terciptanya suasana yang harmonis antara anggota kelompok, maka perlu dibuat aturan main. Kontrol ini sangat penting bagi keberlangsungan kelompok, dengan cara nasihatmenasihati sampai pada tindakan hukuman.

c. Tukar menukar pendapat. Kebiasaan mengeluarkan pendapat dapat memupuk jiwa pemberani dan siap menerima pendapat orang lain walaupun pendapat itu berbeda dengan dirinya.

Pandangan Bennis dan Naus (dalam Maurer, 1994) terhadap belajar bekerja sama (cooperative groups) dalam pembelajaran secara terintegrasi memberi keuntungan yang diungkapkan sebagai berikut:

One benefit of cooperative learning that is seldom mentioned is the unanticipated rise in student self esteem. Because all students use interpersonal skills, because each student's contribution is valued and help bring success to everyone on the team, and becauseeach student can see the immediate effect of his or her contribution, there is felling among student of positive self worth

Berdasarkan pernyataan tersebut, maka proses belajar secara berkelompok dan bekerjasama akan meningkatkan keterampilan sosial peserta didik.

Dalam taksonomi Bloom (Purwanto, 1998: 
45) telah disebutkan bahwa ada tiga domain hasil belajar yang perlu diperhatikan dalam setiap proses belajar mengajar. Tiga domain yang dimaksud adalah kognitif, afektif dan psikomotor (keterampilan). Khususnya pembelajaran dalam bidang keterampilan dijabarkan menjadi empat macam keterampilan, yaitu sebagai berikut:

a. Keterampilan berfikir, kemampuan menguraikan, menjelaskan, menggabungkan, menggolongkan, merangkum, memperkirakan, membandingkan, mempersamakan dan membedakan.

b. Keterampilan akdemis yaitu: kemampuan membaca, menulis, berbicara, mendengarkan, menafsirkan, menyimpulkan, menggambarkan, memetakan, menjelaskan, melukiskan, dan menerangkan.

c. Keterampilan sosial: kemampuan bekerjasama di dalam kelompok (besarkecil), menyumbangkan dan menerima pendapat di dalam tugas dan diskusi, mengembangkan kepemimpinan.

d. Keterampilan meneliti: kemampuan berkreasi dan menemukan hal-hal baru

Gangguan kecemasan sosial adalah satu jenis dari fobia kompleks. Tipe fobia ini memiliki dampak yang merusak, hingga melumpuhkan, pada kehidupan seseorang yang memilikinya. Gangguan ini dapat mempengaruhi kepercayaan diri dan harga diri seseorang, mengganggu hubungan dan kinerja di tempat kerja atau sekolah.

Social anxiety disorder dapat mendatangkan dampak pada kehidupan orang-orang yang menderita kondisi ini. Individu yang memiliki gangguan kecemasan sosial, atau fobia sosial, mungkin memiliki hubungan sosial atau romantis yang sangat terbatas, membuat mereka merasa tidak berdaya, kesepian, bahkan terasingkan. Beberapa orang bisa mengalami cemas dan gugup di situasi tertentu, misalnya menghadapi wawancara kerja. Kecemasan dan kegugupan terkait dengan situasi sosial spesifik tertentu, misalnya: berbicara di depan publik, tampil di atas panggung, bertemu dengan orang baru, menjadi pusat perhatian, diamati ketika melakukan sesuatu, membuat basabasi, digoda, diledek, atau dikritik, berbicara dengan orang-orang penting atau figur yang berwenang, dipanggil dalam kelas, melaksanakan ujian, berbicara saat diskusi kelas. Gejala yang sering muncul yang dialami anak-anak adalah membatasi aktifitas, menghindari tatap muka, berdiam diri di belakang, selalu membawa teman kemanapun pergi, dan menolak untuk pergi ke sekolah.

Zimmerman dan Cunningham (1991) menyatakan: visualisasi adalah proses pembentukan gambar (mental, atau dengan kertas dan pensil atau dengan bantuan teknologi. Visualisasi adalah suatu tindakan dimana seseorang individu membentuk hubungan yang kuat antara internal membangun sesuatu yang diakses diperoleh melalui indra. Sambungan berkualitas tersebut dapat dibuat dalam salah satu dari dua arah. Visualisasi suatu tindakan dapat terdiri dari konstruksi mental setiap objek atau proses yang satu menghubungkan (dalam pikiran) individu dengan objek atau peristiwa yang dirasakan oleh dirinya atau sebagai eksternal. Atau suatu tindakan visualisasi dapat terdiri dari konstruk pada beberapa media eksternal seperti kertas, papan tulis atau komputer, objek atau peristiwa yang mengidentifikasikan individu dengan objek atau proses dalam dirinya atau pikiran.

Arcavi (2003) menyatakan visualisasi pembelajaran dengan kiasan sebagai "melihat yang gaib". Ia menganggap 
pembelajaran sebagai dunia yang lebih "abstrak" berurusan dengan benda-benda dan entitas cukup berbeda dari fenomena fisik, yang meningkatkan kebutuhan untuk bergantung pada visualisasi dalam bentuk yang berbeda dan pada tingkat yang berbeda. Presmeg (1986) mendefinisikan metode visual sebagai salah satu yang memilih gambar visual, dengan atau tanpa diagram, seperti bagian penting dari metode solusi. Metode non visual di sisi lain tidak bergantung pada citra visual.

Peran Visualisasi, Visualisasi memainkan fungsi yang berbeda atau peran pada siswa menggunakannya untuk memecahkan masalah. Ada tujuh (7) peran visualisasi (Presmeg, 1986) :

1) Untuk memahami masalah. Dengan merepresentasi masalah visual, siswa dapat memahami bagaimana unsurunsur dalam masalah berhubungan satu sama lain,

2) Untuk menyederhanakan masalah. Visualisasi memungkinkan siswa untuk mengidenfikasi lebih sederhana versi masalah, pemecahan masalah dan kemudian memformalkan pemahaman soal yang diberikan dan mengidentifikasi metode yang digunakan untuk semua masalah seperti itu,

3) Untuk melihat keterkaitan (koneksi) ke masalah terkait. Ini melibatkan masalah yang berkaitan yang diberikan sebelumnya dalam pengalaman pemecahan masalah,

4) Untuk memenuhi gaya belajar individual. Setiap siswa punya proferensi sendiri ketika menggunakan representasi visual ketika menyelesaikan masalah,

5) Sebagai pengganti untuk komputasi/perhitungan. Jawaban masalah dapat diperoleh secara langsung dari representasi visual itu sendiri, tanpa memerlukan komputasi,

6) Sebagai alat untuk memeriksa solusi. Representasi visual dapat digunakan untuk memeriksa kebenaran dari jawaban yang diperoleh,

7) Untuk mengubah masalah ke dalam bentuk yang konkrit. Bentuk yang konkrit dapat diperoleh dari representasi visual untuk memecahkan masalah.

Kemampuan untuk memecahkan masalah adalah jantung pembelajaran, visualisasi merupakan inti pemecahan masalah pembelajaran. Visualisasi adalah kemampuan untuk melihat dan memahami situasi masalah. Memvisualisasikan suatu situasi atau objek melibatkan “Memanipulasi mental berbagai altenatif untuk memecahkan masalah yang berkaitan dengan suatu situasi atau objek tanpa manfaat manipulative kongkrit.

Ruseffendi (2006 : 78) menyatakan "Sampai abad 20 di AS pengajaran itu untuk melatih otak. Pengetahuan yang dianggap bisa melatih otak itu mata pelajaran yang sukar. Di Indonesia, siswa di sekolah kesulitan dalam belajar yang berkaitan dengan menghafal khususnya dalam memahami permasalahan mempresentasikan apa yang ada dalam pikirannya (visual thinking) dan memecahkan masalah yang sifatnya abstrak padahal pemecahan masalah yang abstrak merupakan jantung dari pembelajaran dan visualisasi merupakan inti dari pembelajaran. Padahal diharapkan pembelajaran, seperti dalam pembelajaran IPS, mengacu pada prinsip siswa belajar aktif, dan "learning how to learn" yang rinciannya termuat dalam empat pilar pendidikan yaitu : (1) learning to know, (2) learning to do, (3) learning to be, dan (4) learning to live together, Kurikulum sekolah memuat rincian topic, kemampuan dasar, dan sikap yang diharapkan dimiliki 
siswa pada jenjang sekolah. Pada hakekatnya belajar adalah berpikir dan berbuat atau mengerjakan.

Gangguan kecemasan sosial adalah satu jenis dari fobia kompleks. Tipe fobia ini memiliki dampak yang merusak, hingga melumpuhkan, pada kehidupan seseorang yang memilikinya. Gangguan ini dapat mempengaruhi kepercayaan diri dan harga diri seseorang, mengganggu hubungan dan kinerja di tempat kerja atau sekolah.

Siswa menggunakan metode visual dalam pemecahan masalah pembelajaran dipengaruhi dua faktor : kebaharuan dari masalah, dan persepsi siswa dari guru mereka dalam preferensi pemecahan masalah. Ternyata bahwa siswa lebih suka menggunakan metode visual untuk masalah soal cerita dan metode non visual untuk soal yang lebih mereka kenal (familiar).

\section{KESIMPULAN}

Berdasarkan analisis data dan pembahasan hasil penelitian yang telah dilakukan dapat diambil kesimpulan terdapat pengaruh Visual Thinking Strategies terhadap pengembangan Keterampilan Sosial (Social Skills) bagi Peserta Didik Social Anxiety Disorder, berdasarkan hasil perhitungan SPSS diperoleh thitung $=2,659$, jika dibandingkan dengan ttabel $=2,020$, maka nilai thitung lebih besar dari ttabel atau $2,659>2,020$.

\section{DAFTAR PUSTAKA}

Arcavi A. (2003). The Role of Visual Representations in the learning of mathematics Educational Studies in Mathematics, 52, 215-241.

Carlos Salavera, C; Pablo Usan; Laurane Jarie, Emotional intelligence and social skills on self-efficacy in
Secondary Education students. Are there gender differences? Journal of Adolescence 60 (2017) 39-46, http://dx.doi.org/10.1016/j.adolesce nce.2017.07.009

Heather Lorna Rumney, Ken MacMahon, Do Social Skills Interventions Positively Influence Mood in Children and Young People with Autism? A Systematic Review, Mental Health \& Prevention, accepted 2016, S22126570(16)30039-3,

http://dx.doi.org/10.1016/j.mhp.201 6.12 .001

Jarolimek (1997). Social Studies Competencies and Skills. New York : Macmillan Publishing Co., Inc

Jarolimek dan Parker. (1993). Social Studies in Elementry Education. New York: Mc Millan Publishing.

Lau, E.X. Lau; Ronald M. Rapee; Robert J. Coplan, "Combining child social skills training with a parent early intervention program for inhibited preschool children", Journal of Anxiety Disorders, 2017, accepted manuscript, DOI: http://dx.doi.org/10.1016/j.janxdis.2 017.08.007

Martine L. Broekhuizena, Irina L. Mokrovab, Margaret R. Burchinalb,Patricia T. GarrettPetersb, The Family Life Project Key Investigators, Classroom quality at pre-kindergarten and kindergarten andchildren's social skills and behavior problem, Early Childhood Research Quarterly $36 \quad$ (2016) http://dx.doi.org/10.1016/j.ecresq.20 16.01.005, 212-222,

Maurer, R.E. (1994). Designing Interdisciplinary Curriculum In 


\section{Jurnal}

Middle Junior High and High Scools. New York: Allyn and Bacon Rao, Patricia A.; Deborah C. Beidel; Michael J. Murray, "Social Skills Interventions for Children with Asperger's Syndrome or HighFunctioning Autism: A Review and Recommendations", J Autism Dev Disord (2008) 38:353-361, DOI 10.1007/s10803-007-0402-4

Ruseffendi, H.E.T. 2006. Pengantar kepada membantu Guru Mengembangkan Kompetensinya dalam pengajaran Matematika untuk Meningkatkan CBSA. Tarsito Bandung.

Sjamsuddin, H dan Maryani, E. (2008). "Pengembangan Program Pembelajaran IPS untuk Meningkatkan Kompetensi Keterampilan Sosial" . Makalah pada Seminar Nasional, Makasar.

Sunal, C dan Haas, M. ( 2005). Social Studies For Elementary and Middle Grades A Constructivist Approach .2th US : Pearson Educaiton. 